\title{
New HTLV-1 and HTLV-2 infections in rural population, in North of Gabon, Central Africa
}

\author{
Augustin Mouinga Ondeme ${ }^{1 *}$, Rodrigue Bikangui ${ }^{1}$, Ulrick Bisvigou ${ }^{2}$, Paul Ngari' $^{1}$, François Rouet ${ }^{1}$ \\ From Frontiers of Retrovirology: Complex retroviruses, retroelements and their hosts \\ Cambridge, UK. 16-18 September 2013
}

\section{Background}

The emergence of Human retroviruses, in Central Africa, may occur in contact with non human primates, during hunting and butchering. Recent studies described several cases of human infections with Human T-cell Lymphotropic Virus (HTLV) as the result of simian zoonotic transmissions, in south Cameroon corresponding to north Gabon.

To search for new HTLV infections (HTLV-1, HTLV-2) and to investigate zoonotic infection, we conducted a study among individuals hunting and butchering of wild non-human primates, in rural area in north of Gabon, Central Africa.

\section{Materials and methods}

This study was conducted during 2 weeks in May 2013, in rural villages in Gabon. We studied 222 people, with 15 years and up, from the general adult population (mean age 55 years, 61 women and 162 men) experiencing hunting or butchering. Blood was collected in EDTA tube, and HTLV-1/2 immunoenzymatic test (ELISA) was performed as a screening test. Because of the unavailability of the Western Blot tests during the study, Positive samples were confirmed and discriminated by PCR in tax-rex region with specific primers. Phylogenetic analyses using Neighbour-Joining were done.

\section{Results}

Among a total of 222 persons, seropositivity in HTLV was found in $18(8.10 \%), 5$ (2.25\%) were women and 13 (5.85\%) men. Men were hunters while women recognized butchering activities. PCR of 18 samples showed that 5 were HTLV-1 positive ( 2 men and 3 women);

${ }^{1}$ Laboratoire de Rétrovirologie, Centre International de Recherches Médicales de Franceville (CIRMF), Franceville, Gabon

Full list of author information is available at the end of the article one HTLV-2, isolated from a hunter; 12 were not amplified ( 5 of them showed a high optic density by serology). Phylogenetic analysis confirmed PCR results obtained for HTLV-1 and HTLV-2.

\section{Conclusions}

Our results show HTLV-1 and HTLV-2 Infections in a risk group in north of Gabon, corresponding to south of Cameroon, Central Africa. These results suggest a probable simian origin of HTLV-1 and HTLV-2 described subtypes. Further studies are needed to best understand the interspecies transmission of these complex retroviruses; and to explore the intra familial transmission.

\section{Authors' details}

'Laboratoire de Rétrovirologie, Centre International de Recherches Médicales de Franceville (CIRMF), Franceville, Gabon. ${ }^{2}$ Unité de Recherche et d'Analyses Médicales, CIRMF, Franceville, Gabon.

Published: 11 October 2013

doi:10.1186/1742-4690-10-S1-P110

Cite this article as: Ondeme et al: New HTLV-1 and HTLV-2 infections in rural population, in North of Gabon, Central Africa. Retrovirology 2013 10(Suppl 1):P110

Submit your next manuscript to BioMed Central and take full advantage of:

- Convenient online submission

- Thorough peer review

- No space constraints or color figure charges

- Immediate publication on acceptance

- Inclusion in PubMed, CAS, Scopus and Google Scholar

- Research which is freely available for redistribution

Submit your manuscript at www.biomedcentral.com/submit 